\title{
Adult Learning Development from the Prism of Homestay
}

\author{
Onwubiko Emeka Cyprian ${ }^{1}$ \\ ${ }^{1}$ Department of Human Resource Development, University Putra Malaysia, Selangor, Malaysia \\ Correspondence: Onwubiko Emeka Cyprian, Department of Human Resource Development, University Putra \\ Malaysia, Selangor, Malaysia. E-mail: candidmecus@yahoo.com
}

Received: June 18, 2012 Accepted: July 2, 2012 Online Published: August 22, 2012

doi:10.5539/hes.v2n3p77 URL: http://dx.doi.org/10.5539/hes.v2n3p77

\begin{abstract}
This study seeks to understand how adult learning takes place in homestay programme at Kanchong Darat, Banting, and Selangor in Malaysia. The study seeks to provide an overview evaluation and some salient lessons that could be derived in providing quality homestay services to learners. More so, the study succinctly covers socio-cultural issues in the homestay environment, such as the general services, and policy governing the programme. Furthermore, the study looks at the qualification requirements for participation in the homestay programme. It also apprised readers on how adult learning has changed dramatically over the years through self-directed knowledge and skills acquisition in the homestay arrangement. In addition, the study brings to fore some issues and challenges that the operators and learners encounter in homestay programme in Malaysia. The study indicated that adult learners in homestay programme arrangement learn through their experiences, and are mostly self-directed in learning. Questionnaires, interview, and observation were used in the study.
\end{abstract}

Keywords: adult learners, adult education, homestay operators, homestay programme, skill, program evaluation

\section{Introduction}

Adult learners enrol in learning activities through varying channels that are meaningful to them. It is then unsurprising that adult learning is a complex phenomenon, and it is difficult to capture in any definite definition (Cranton, P., 1994). One of the key vital supports that enhance adult learning is having an effective learning environment that provides for both adult's physical and psychological needs. This kind of learning environment will enable a successful partnership among learners and instructors (Imel, 1994). The homestay programme is a potential tourism sector that could attract people of diverse cultural background, since there is a market demand by the international visitors (Richardson, 2003). As a part of learning, homestay programme is characterised by the increasing demand of knowledge through observing, learning the customs and norms of the host community. For example, students who study overseas often participate in homestay programme, and learn numerous things in the cause of doing that (Learning and Teaching Support Network, 2004).

Thus, homestay programme offers participants opportunity to interact as well as to experience firsthand the culture of the host community, to experience their cultural heritage directly, and it gives them the avenue for learning. In Malaysia to be precise, the programme was introduced by the Ministry of Tourism Malaysia in 1988 as an effort to diversify the tourism sector through the provision of an alternative accommodation for tourists.

More importantly, there is no existing research on the importance of adult learning in homestay experience among the participants. And there is little academic research work to this date that document why participants choose to engage in such venture as the homestay programme, unlike in Australia and New Zealand where it is extensively documented.

\subsection{Study Problem}

The Stars dated June 9, 2009 reported the statements by Tourism Minister Datuk Seri Dr Ng Yen Yen in Kota Kinabalu about ruling out the more stringent rules for homestay learners in consonance with the true Malaysian experience as the tourism hub of the world. She was quoted as saying, "Homestay operators will have to follow a set of strict guidelines to ensure that visitors will get the real experience of local living and culture". She added, "The operators must interact with their guests, teach them at least one local song and dance, and served them with local delicacies so that they would get the real taste of the Malaysian experience and wish to visit again." She further said "...there are many tourists who want to experience more of Malaysian life than having just leisure and recreation visit only". Hence, homestay is not only fostering intercultural relations and increasing 
intercultural understanding, but it has also been suggested to provide the learners with educational opportunity (Clayton, 1984). However, the roles and experiences of homestay operators and learners have been neglected at large in the literature. Therefore, the study seeks to find out more about homestay programme and to documents the practical issues involved in the programme.

\subsection{Objectives of Study}

The objectives of this research are:

a) To identify who are participants in homestay programme;

b) To understand why adults participate in homestay programme;

c) To find out whether host communities have developed a unique experience from homestay;

d) To ascertain if the operators and the learners are obtaining fair return for their services and investment;

e) To discover issues and challenges faced by the participants in homestay.

\section{Review of Literature}

\subsection{Clash of Culture and Learning in Homestay}

There is no much academic research addressing issues related to homestay as a part of Adult education activity. As aforementioned, there is little research on this sector and this is why some of the literature in the field is scanty (Clayton, 1984). However, homestay has become an integral part of global education for both students and institutions of learning; it also plays a role in fostering intercultural relations and understanding. Kamal (2008) opined that to identify differences between those who live in urban areas and those who live in rural areas need to be construed to avert culture clash.

In several studies, Van Bael, et al.,( 2002) opined that "the main intercultural issues identified by providers were related to food, communication barriers, differences in attitudes toward family and gender roles, cultural "dos" and "don'ts", behaviour and moral values and privacy issues in terms of maintaining personal space". This could also be described as symptoms of culture clash (Seelye \& Seelye-James, 1995). Ward \& Masgoret (2004); and Akbar (2004), identified the connection or rather relationship that a student develops with the homestay family as an important aspect to the student's satisfaction and adjustment. While, (Finegan, et. al, 1997) pinpointed the ideas of politeness in culture, whereas, (Hofstede, 1997) identified the appropriate interactions within different social settings.

According to Richardson (2003), "homestay refers to the concept of sojourners residing with a family within a target culture". As such, it is a means of cross cultural learning exchange for the participants who are mostly adults. "Homestay accommodation is a term with specific cultural associations" (Learning and Teaching Support Network, 2004). According to several scholars, there are ideological variation arising from diversity between cultures and units of the cultures include the way people from the target culture interact with those of low target language proficiency (Berry et al 1997; Berry 2005; Ellis, 1994; Ward \& Kennedy, 1999; Cushner \& Brislin 1997; Brown \& Holloway 2007; Hecjanova-Ampay, et al 2002; Garson, 2005).

From the aforementioned, it can be said that the acculturation process will affect all people moving to a new culture for one thing or the other and it will affect most of those whose home culture is different from the host culture. Nevertheless, homestay accommodation is a situation where such difference in culture can be very visible because of the interaction going on among the learners, participants, and the host family.

\subsection{Adult Education and Participants}

According to Knowles, Horton, and Swanson, M. (2005), asserted that "adult learner can be describe as any person socially accepted as an adult who is in a learning process, whether it is formal education, informal learning or corporate sponsored learning." In spite the differences in the definition of an adult learner, a generic profile of adult learners can be any person socially accepted as adult who is in a learning process. In the same vein, the contrast between pedagogy and andragogy give more explication on who is adult learner. Pedagogy describes the traditional instructional approach of learning based on teacher-directed learning theory, whereas Andragogy describes the approach based on self-directed learning theory. The latter, is appropriate for adult. Malcolm Knowles, a recognized leader in the field of adult education, coined the term andragogy from the Greek words "aner", meaning adult, and "agogus", meaning guide, to describe the art and science of helping adults learn (Knowles, 1992).

Adult education has two dual motives, namely growth or life-space motivation and deficiency or life-chance motivation. "Growth or life-space oriented people participate in adult education for expression rather than in an attempt to cope with some aspect of their life; life-chance oriented people participate because of the need to 
survive and acquire utilitarian knowledge, attitudes or skills" (Boshier, 1977, p. 92). Boshier, (1977) also indicated that life-chance motivated participants are largely attempting to satisfy the lower-order needs on Maslow's hierarchy such as physiological needs, safety needs, love and belongingness and esteem needs, while life-space motivated participants have largely satisfied the lower-order needs and are primarily enrolled to expand their life- space such as self-actualising need. In the same vein, most participants in homestay programme are adults who integrate with other people gregariously, share some needs and show sense of belongingness.

\subsection{Adult Learning and Development}

Learning is considered as a central process of human being (Merriam, et. al 2007). Adult learning processes involve other external and internal factors that can stimulate and motivate the learner's attention. According to Merriam, Cafarella \& Baumgartner (2007), "there is no single theory and model that can explain all learning by human." The most common used models to explain the human learning are Knowles' andragogy, McClusky's theory of margin, Knud Illeris's three dimensions of learning model, Jarvis's learning process, self-directed learning, transformational learning, experiential learning,. Adults will go through some changes throughout their life span and this will have implications on their learning. These changes are the results of a development process. There are quite extensive numbers of theories related to adult development and one of the theorists was Erik Erikson. As psycho-analyst, he describes the physical, emotional and psychological stages of development and relates specific issues, or developmental work or tasks, to each stage. For example, if an infant's physical and emotional needs are met sufficiently, the infant completes his/her task by developing the ability to trust others. However, a person who is stymied in an attempt at task mastery may go on to the next state but carries with him or her remnants of the unfinished task. For instance, if a toddler is not allowed to learn by doing, the toddler develops a sense of doubt in his or her abilities, which may complicate later attempts at independence.

One example of such case occurred in homestay programme which some volunteers opted to involve in a homestay programme in Gibbon Rehabilitation in Thailand. The outcomes of volunteering were investigated; it was found that they were living in shared accommodation at the project headquarters in a small village on the island in Thailand. The Volunteers were able to be immersed in the Thai culture and way of life and "contributed to 'personal growth' and a 'changed view of the world' as some of the benefits of volunteering while undertaking such activities" (Broad, 2003). In this instance the Volunteers did learn while on that particular visit through their experiences. As Walter, (2009) said “...tourists to learn experientially, to understand and appreciate local knowledge, and in the process, contribute to the sustenance of the community" (p. 513). This has demonstrated that the notion of homestay is to bring people from different cultural background with the disposition to have shared knowledge and experience and that is part of the learning process as adult learners.

\section{Methodology}

The method employed in this study involved both primary and secondary sources (qualitative research paradigm) The study used primary data based on the responses from the participants of the study, and the secondary data was based on books, reports, articles, journals, and other documents related to homestay programme. During the study, face to face interviews and observation were conducted while questionnaires were distributed in collecting information from a wider sample that cannot be reached by the interview sessions.

\subsection{Participant}

Total area of Kanchong Darat village is around $35 \mathrm{~km}$ square feet; consist of 10,000 peoples and 500 households. From that figure, only 38 houses (7.6\%) are endorsed and registered by MOTOUR and the State Tourism Action Council and these 38 household were purposively recruited in this study (Fine \& Weis, 2000). The characteristics of each group are described below:

Key Informants: Key informants were the reference point for this review and thus recruited on the basis of their long standing involvement with the programme. These consist two of the current and one past providers of the homestay programme who also assisted with the recruitment, interpretation, and distribution of the questionnaires, as well as during the interviews sessions.

Homestay Learners and Family (Provider): Using the "homestay learners and family (provider)", the participants in the interview sessions who were selected on the basis of experience in the homestay programme as well those learning.

\subsection{Data Collection}

The study took place in Kanchong Darat Homestay located in Banting, Selangor. In the process of gathering 
knowledge and information related, our research team did visit the place three times which were on 23rd January, 3rd February, and 3rd March 2010 respectively. Besides, the two training programmes conducted by the Ministry of Tourism. We also attended another session of programme where the learners (operators) accepted a group of students from the University of Technology Mara in Malaysia starting on 17th to 20th February, 2010. The main purpose for the visit is to observe the learners participation, the management of the programme and to learn the programme dedicated to the students in the event.

The research instruments used in the study were questionnaire, interview and observation. To be more explicit the following were used:

Questionnaire: The questionnaires constitute of 28 questions were based on the brochures and website on the homestay programme as to gather relevant information from the respondents and was conducted in both Bahasa Malaysia and English. A set of questionnaires used for data collections are attached herein and marked as Appendix I. Generally, the used of questionnaire was to get the learners' profiles, reasons of joining the programme, if the programme is beneficial, and the barriers of their learning.

Interview: The interview sessions were conducted face to face with the person in charge of the homestay programme, and his wife whom was at the secretariat for homestay programme. It was conducted during our first and second visit as to gather information about who participated in the homestay, why they participate in the programme, what motivates them to join the programme, and the benefits they gain throughout the programmes. A set of interview questions are enclosed and marked as Appendix II.

Observation: The researcher also managed to observe two programmes which have been conducted by Ministry of Tourism on Hotel Management and by Institute for Rural Advancement (INFRA) on Philosophy of Rural and Village Action Plan. Observations were made in relation to the methods or techniques used by the trainers and how the adult learners participate through the learning process.

\section{Result}

\subsection{Learner's Characteristic}

All 38 set of questionnaires were fairly distributed to all operators. However, only 28 respondents $(74 \%)$ return the complete form. Based on these data, the learners who participated in the homestay programme are adults from various stages of experience and exposure. The majority of them are male gender which constitute $29(76 \%)$ of overall 38 participants, self- employed and also housewives. Their ages ranging from 50 years old and above, with the exception of one person who is 45 years old and he is still working as government official. The samples comprised of $100 \%$ Javanese Malay with $89 \%$.

\subsection{Motive and Hindrance in Learning}

Based on the findings, adults who were involved in homestay programme were motivated because many of them felt bored. Majority of them said they sought to avert solitary situation because many of their loved ones who are grown had left them; some have migrated to urban areas to fend for themselves, others have married and are living with their respective families. Those respondents who said desolation was the major reason for joining the homestay programme constituted about $61 \%$ from 36 learners who participated during the training programme conducted by the ministry and INFRA. This factor has become one of the major reasons why most of the participants got involved in the programme. Another notable factor the respondents presented was monetary reward which constituted $25 \%$, the findings indicated that the income for each learner is ranging from RM500 to RM2000 and as additional to cover household income; this informed why most of them participated in the programme. Besides this factor, majority of them said they benefited in learning new skills through networking with participants in the homestay programme, homestay operators, homestay committee members at national level, as well as having the opportunity to visit neighbouring countries to broaden their scope of learning.

In addition, there were other issues or challenges they raised, the participants are mostly above 50 years old that made up (96\% of participants), and some of them have health issues like poor sight and sense of hearing. Thus, such factors make their learning process slow. They also lamented that they are having problems of accessing funding from the Government of Malaysia to operate. The learners also said there are scanty sceneries or tourist attraction sites in the vicinity. They also lamented that most young Malaysian adults are not interested in learning making the future of homestay in Malaysia blink if the tendentious pattern persists.

\subsection{Adult Learning in Homestay Arrangement}

Referring to the learning process experienced by adults in the homestay programme, this study focuses on the traditional learning theory of Behaviourist and Knud Illeris (2003) "Three Dimensions of Learning Model”. This 
study has found that both Behaviourist approach and Three Dimension Model are most suited in relation with adult participation in the homestay programme. Behaviourist approach promotes the idea that learning is a process that involves overt change and observable behaviour among the participants. Behaviourist approach emphasises that the courses and contents of learning are controlled by stimuli in the external environment. In homestay participants expect economic gain and desire to avert solitary condition and these are the major stimuli that motivate the adults who participate in the homestay program to learn. The major learning purpose among the learners is to obtain accredited homestay certificate which enable them to join the programme as operators. Apart from attending five (5) days compulsory course arranged by the Ministry of Tourism, the participants have to attend series of additional courses, seminars and workshops namely Seminar Homestay Negeri Selangor, Kursus Eco Pelancongan, Seminar on Japanese Tourism Industry, National Think Tourism Summit and Seminar On Japanese Tourism Industry (Japanese Language IAPEC).

Another learning approach in this homestay study is Knud Illeris (2003)'s Three Dimensions of Learning which stresses on the usage of cognition, emotion and social processes while learning take place. These three dimensions are interrelated with each other; all learning aspects occur within the society and have significant impact on the adult's motivation towards acquiring knowledge. The learning process involves cognition, emotion, environment cognition, emotion, and society interchangeably. They learnt to read, which involved both cognitive, and emotional dimension.

\subsection{Learning Outcomes via Homestay}

For the learning outcome, the trainings and courses that the adult learners involved in the homestay programme were very positive outcomes. In congruent with the Behaviourist approach, the participants experienced behavioural and attitudinal changes on certain aspects. The study showed that some behavioural change was borne out of the need to get the reward offered through the homestay learning activity. They said that the learning activities have helped them to operate their homestay projects confidently and they are able to conduct many programmes required from them. They also earned good recommendation for their social skills and networking abilities compared with those who are not involved. These have accumulated to a unique experience in dealing with the tourists and it kept on growing as they progressed, they are also able to gain fair return on investment since according to Chairman of the homestay programme, he said that each and every operator gets extra income for their family. Besides the allocation provided by Ministry of Tourism lately, the government built better toilets to the eleven operators and discounted water filter price for each of the participant.

Knud Illeris (2003)'s "Three Dimension of Learning Model", the learning outcomes that can be deduced from the study was in consonance with the views that adults are more creative and innovative in their thinking, since they have to meet their needs and the demands from all kind of visitors, thereby making it a cognitive activity. In terms of the demonstration of emotion, it was reported they are hospitable to the participants in the homestay, and thereby living memorable imprints on the visitors. As a social process, they also improve their level of social networking and to arrange their own contact groups nationwide (locally). They used their cognitive and emotional dimension to learn new knowledge while attending courses and also involve social interaction with fellow participants in the homestay programme.

\section{Analysis}

Merriam and Caffarella (1999) asserted that women are more likely than men to participate in adult education activities, but it holds no water in this study. In contrast, the findings in this study showed that men are the majority, they constituted 29 (76\%) of 38 participants. They are more likely to participate since they have varying needs to meet. In another vein, the study found out that there have been differences in culture and languages used; many of the learners did encounter problems of mastering the language because of language barrier. This was because the majority of them was above 50 years old and has health issues. Therefore, this is coherent with what Bee \& Bjorklund (2004) who opined that older learners are slow learners than younger learners.

It indicated that the older participants need more time to learn new things. As Knowles (1980), andragogical assumptions is in congruent with the findings of the study which opined that during the process of maturation, a person moves from dependency toward independency, but at different stages for different people and in different dimensions of life. In addition teachers have responsibilities to encourage and nurture this maturation stages in the learner. Generally, adult learners have deep psychological needs to be self-directed, but they may be dependent temporary in certain insinuations. The study also found that during initial stage when the learners started the homestay programme, lots of challenges and barriers were common. They had to start from the scratch to source for fund and they ensured also they have proper infrastructure and accommodations, as it the 
set of rules by Ministry of Tourism before the government gives anyone license to operate the homestay programme.

In another vein, there were various disagreements as to what is the real concept of homestay. Sometimes this has become very problematic for the operators to convey to the learners on what the homestay concept is all about. For some of the respondents, homestay means living together with the operators by doing what they did and eating what they ate. As for others, it means living in a different domain outside their place of domicile, similar to what hotel the concept is all about. Therefore, there is no given consensus among the respondents on the concept of homestay programme.

\section{Conclusion}

Adult learners involve in homestay programme learn their skills in social networking with other people of devised culture, background, norms, and beliefs. This study indicated that adult learners learn through their experiences and are mostly self-directed in learning. Therefore, the success or failure of learning process depends on the adults themselves as the participants. And learning can be worthwhile when they attach importance to such a venture.

The study of Kanchong Darat, Banting, Selangor, has provided a contextual understanding of the process in homestay programme as it gives to those in authority the opportunity to look extensively at many aspects of the service and operation of homestay in Malaysia. Furthermore, what was considered to be a successful homestay programme, for long, relied on the experience, skills and cultural knowledge of the homestay operators with many challenges as illustrated in the result and discussion. In one instance, the learners during the implementation of programme have some pressing problems by which sometimes there are a limited number of participants joining the homestay programme with lesser than 38 operators (learners). There is then an immediate need for guidelines, policies, procedures, and improved communication with all stakeholders in the homestay interactive context. More importantly, the ongoing training for homestay learners or operators should be encouraged, and there is the utmost need to regularly review the programme for optimal performance. Lastly, since this study does not claim generalisation of the findings. It is then recommended that there should be other academic research conducted extensively in this topic or other areas of concern in the future.

\section{Recommendation}

a) The government should have workable and organised programme for the homestay sites in Malaysia. This plan can be deployed so that visitors and local communities will gain more knowledge of tourism management and the process as well. More importantly, traditional owners of the areas should be recognised and the traditional culture should not be in conflict with the homestay programme.

b) There should be sensitisation and increase in publicity in both print and electronic media on those homestay destinations to attract learners, tourists, and investors both locally and internationally respectively.

c) There should be incentives to the learners, and the government should make homestay as the pride sector of the nation as to motivate citizens to take it as their heritage and to take active part to promote it both locally and internationally.

d) The Ministry of Tourism in Malaysia should provide assistance by providing technical expertise, thus, conducting a training programme with the involvement of younger participants from various homestay programme should be encouraged so that they could learn and benefit in the sector. In lieu to this, they should inculcate the programmes in the schools' curricular in Malaysia to enable younger learners to buy to it.

\section{Acknowledgment}

This study could not have been conducted without my lecturers and course mates at the Universiti Putra Malaysia who not only served as my mentors and friends but also encouraged and challenged me throughout my academic programme. I also thank Dr. Adrian Cherney of The University of Queensland Australia who is my $\mathrm{PhD}$ assigned supervisor who encouraged me to write academic articles. To my family, friends, and my partner Lynette Wright, words alone cannot express what I owe them for their encouragements and whose patience and love enabled me to complete this article.

\section{References}

Akbar, H. (2004). Evaluating the QUT Homestay Policy. Paper presented at the ISANA Conference, Melbourne, Australia.

Bael, T. V., Hassan, Y., \& Akbar, H. (2002). QUT Homestay Program Evaluation Report. Brisbane: International 
Student Services, QUT.

Bee, H. L., \& Bjorklund, B. (2004). The Journey of Adulthood (5th ed.). New Jersey: Prentice Hall.

Berry, J. W. (2005). Living successfully in two cultures. International Journal of Intercultural Relations, 29 , 697-712. http://dx.doi.org/10.1016/j.ijintrel.2005.07.013

Berry, J. W., Segall, M. H., \& Kagitcibas, C. (Eds.). (1997). Handbook of Cross-Cultural Psychology, 3: Social Behavior and Applications. Needham Heights, MA: Allyn \& Bacon.

Boshier, R. (1977). Motivational orientations re-visited: Life-space motives and the education participation scale. Adult Education Quarterly, 27(2), 89-115. http://dx.doi.org/10.1177/074171367702700202

Boshier, R., \& Collins, J. B. (1985). The Houle Typology After Twenty-Two Years: A Large Scale Empirical Test. Adult Education Quarterly, 113-130. http://dx.doi.org/10.1177/0001848185035003001

Broad, S. (2003). Living the Thai Life-A Case Study of Volunteer Tourism at the Gibbon Rehabilitation Project, Thailand. Tourism Recreation Research, 28(3), 63.

Brown, L., \& Holloway, I. (2007). The initial stage of the international sojourn: Excitement or culture shock? British Journal of Guidance and Counseling, 36(1), 33-49. http://dx.doi.org/10.1080/03069880701715689

Clayton, L. (1984). When do you bow in Australia?. Sydney: AFS.

Cranton, P. (1994). Understanding and Promoting Transformative Learning. San Francisco: Jossey-Bass.

Cross, K. P. (1981). Adult as learners: Increasing participation and facilitating learning. San Francisco: Jossey-Bass.

Cushner, K., \& Brislin, R. W. (Eds.). (1997). Improving Intercultural Interactions: Modules for Cross-Cultural Training Programs. Thousand Oaks, California: Sage Publications.

Ellis, R. (1994). The study of second language acquisition. Oxford: Oxford University Press.

Fine, M., \& Weis, L. (2000). Speed Bumps: A Student Friendly Guide to Qualitative Research. New York: Teachers College Press.

Finegan, E., Blair, D., \& Collins, P. (1997). Language: Its structure and use. Sydney: Harcourt Brace.

Garson, B. (2005). Teaching Abroad: A Cross-Cultural Journey. Journal of Education for Business, 80(6), 322. http://dx.doi.org/10.3200/JOEB.80.6.322-326

Hatch, S. (2005). Conceptualizing and identifying cumulative adversity and protective resources: Implications for understanding health inequalities. Journal of Gerontology: Social Sciences, 60, 130-134. http://dx.doi.org/10.1093/geronb/60.Special_Issue_2.S130

Hecjanova-Ampay, R., Beehr, A. B., Christiansen, N. D., \& Van Horn, R. K. (2002). Adjustment and Strain among Domestic and International Student Sojourners: A Longitudinal Study. School Psychology International, 23, 458. http://dx.doi.org/10.1177/0143034302234007

Hlebowitsh, P. S. (1992). Amid Behavioral and Behavioralistic Objectives: Reappraising Appraisals of the Tyler Rationale. Journal of Curriculum Studies, 24(6), 553-547. http://dx.doi.org/10.1080/0022027920240602.

Hofstede, G. (1997). Cultural differences in teaching and learning. International Journal of Intercultural Relations, 10, 310-320.

Illeris, K. (2003). Three Dimensions of Learning: Contemporary learning theory in the tension field between the cognitive, the emotional and the social. Malabar, FL: Krieger.

Imel, S. (1994). Guidelines for Working with Adult Learners. ERIC Digest, 154. Columbus: ERIC Clearinghouse on Adult, Career and Vocational Education, Center on Education and Training for Employment, the Ohio State University.

Kamal, M. (2008). Working with Middle-Eastern, Arabic Native speakers and Muslim students. A workshop conducted in conjunction with the ISANA annual conference, Auckland, NZ.

Knowles, J. G. (1992). Models for understanding pre-service and beginning teachers' biogra-phies: Illustrations from case studies. In Goodson, I. F. (Ed.), Studying teachers' lives (pp. 99-152). New York: Teachers College Press.

Knowles, M. S. (1980). The Modern Practice of Adult Education: From Pedagogy to Andragogy (2nd ed.). New York: Cambridge Books. 
Knowles, M., Horton, E., \& Swanson, R. (2005). The adult learner: The definitive classic in adult education and human resource development. Amsterdam: Elsevier.

Knox, A. (1977). Adult Learning and Development. San Francisco: Jossey-Bass.

Learning and Teaching Support Network. (2004). Homestay accommodation sector. Retrieved January, 2004 from Hospitality, Leisure, Sport \& Tourism web site: http://www.hlst.ltsn.ac.uk/about/aboutus.html

Merriam, S. B., \& Caffarella, R. S. (1999). Learning in adulthood: A comprehensive guide (2nd ed.). San Francisco, CA: Jossey-Bass.

Merriam, S. B., Cafarella, R. S., \& Baumgartner, L. M. (2007). Learning in Adulthood: A Comprehensive Guide. San Francisco: Jossey-Bass.

Richardson, K. (2003). International Education: Homestay Theory Versus Practice. Proceedings for the International Education Research Conference AARE-NZARE, 30th November-3rd December, 2003, Auckland, New Zealand.

Russell K. B. (2003). A Framework for Design and Evaluation of Internet-Based Distance Learning Courses Phase One-Framework Justification, Design and Evaluation. Online Journal of Distance Learning Administration, 6(2). State University of West Georgia, Distance Education Center.

Seelye, H., \& Seelye-James, A. (1995).Culture Clash. Ned. Lincolnwood: Illinois NTC Business Books.

Tyler, R. W. (1949). Basic Principles of Curriculum and Instruction. Chicago: University of Chicago Press.

Walter, P. (2009). Local knowledge and adult learning in environmental adult education: Community-based ecotourism in southern Thailand. International Journal of Lifelong Education, 28(4), 513-532. http://dx.doi.org/10.1080/02601370903031363

Ward, C., \& Kennedy, A. (1999). The Measurement of Sociocultural Adaptation. International Journal of Intercultural Relations, 23(4), 659-677. http://dx.doi.org/10.1016/S0147-1767(99)00014-0

Ward, C., \& Masgoret, A. (2004). The Experiences of International Students in New Zealand. A Report prepared for the Ministry of Education.

\section{Appendices}

I. Questionnaire on the implementation of homestay programme

Kajian ini dijalankan adalah untuk meninjau pendapat umum tentang pelaksanaan program homestay di Kampung Kanchong Darat, Banting, Selangor. Segala maklumat yang diperolehi adalah sulit dan tidak akan didedahkan kepada mana-mana pihak kecuali untuk kebaikan bersama pihak yang terlibat secara langsung dengan program ini.

The purpose of this study is to seek the public views about the implementation of homestay programme in Kanchong Darat Village, Banting, Selangor, Malaysia. All the information gathered from this research is confidential. Only members of committee and relevant parties in relation to this programme are allowed to access the information related to this research.

Soal selidik ini mengadungi dua bahagian, (Bahagian Satu dan Bahagian Dua). Sila jawab kedua-dua bahagian.

This survey consists of two parts (Part One \& Part Two). Please answer both parts. 


\begin{tabular}{|c|c|c|}
\hline \multicolumn{3}{|c|}{$\begin{array}{l}\text { BAHAGIAN SATU - Sila tanda } \sqrt{ } \text { satu jawapan sahaja } \\
\text { PART ONE - Please tick } \sqrt{ } \text { one answer only }\end{array}$} \\
\hline \multirow{2}{*}{ Jantina / Gender: } & \multicolumn{2}{|l|}{ Lelaki / Male } \\
\hline & \multicolumn{2}{|l|}{ Perempuan / Female } \\
\hline \multirow{5}{*}{ Umur / Age: } & \multicolumn{2}{|l|}{18 ke bawah / below 18} \\
\hline & \multicolumn{2}{|l|}{$19-29$} \\
\hline & \multicolumn{2}{|l|}{$30-39$} \\
\hline & \multicolumn{2}{|l|}{$40-49$} \\
\hline & \multicolumn{2}{|l|}{50 ke atas / above 50} \\
\hline \multirow{4}{*}{ Bangsa / Race } & \multicolumn{2}{|l|}{ Malay / Malay } \\
\hline & \multicolumn{2}{|l|}{ Cina / Cina } \\
\hline & \multicolumn{2}{|l|}{ India / India } \\
\hline & \multicolumn{2}{|c|}{ Lain-lain / Other } \\
\hline \multirow{6}{*}{$\begin{array}{l}\text { Kelayakan Tertinggi } \\
\text { / Highest Qualification: }\end{array}$} & \multicolumn{2}{|c|}{ Sekolah Rendah / Primary School } \\
\hline & \multicolumn{2}{|c|}{ SPM / O-Level } \\
\hline & \multicolumn{2}{|l|}{ STPM / A-Level } \\
\hline & \multicolumn{2}{|c|}{ Ijazah Sarjana Muda / Bachelor's Degree } \\
\hline & \multicolumn{2}{|c|}{ Ijazah Sarjana / Master's Degree } \\
\hline & \multicolumn{2}{|c|}{ Lain-lain / Other } \\
\hline \multirow{4}{*}{$\begin{array}{l}\text { Status Perkahwinan } \\
\text { / Marital status: }\end{array}$} & \multicolumn{2}{|l|}{ Bujang / Single } \\
\hline & \multicolumn{2}{|l|}{ Berkahwin / Married } \\
\hline & \multicolumn{2}{|l|}{ Bercerai / Divorced } \\
\hline & \multicolumn{2}{|l|}{ Lain-lain / Other } \\
\hline & \multicolumn{2}{|l|}{ Kerajaan / Government } \\
\hline Perkerjaan & Swasta / Private & \\
\hline & Lain-lain / Other & \\
\hline & RM 1,000 ke bawah / be & 1,000 \\
\hline & RM 1,000 - RM 2,000 & \\
\hline Pendapatan & RM 2,000 - RM 3,000 & \\
\hline / Monthly income: & RM 3,000 - RM 4,000 & \\
\hline & RM 4,000 ke atas / abov & 000 \\
\hline & Lain-Lain / Other & \\
\hline $\begin{array}{l}\text { Jumlah ahli keluarga } \\
\text { /Number of family members: }\end{array}$ & Sila nyatakan / Please st & \\
\hline & Kurang dari 12 tahun $/ b$ & an 12 years old \\
\hline Umur anak & 13 hingga 17 tahun / 13 & ars old \\
\hline & 18 tahun dan ke atas / 18 & ld \& above \\
\hline & Penglihatan / Vision & Jelas / Clear \\
\hline & & Tak Jelas / Not clear \\
\hline & Pendengaran / Hearing & Jelas / Clear \\
\hline Tahap kesihatan & & Tak Jelas / Not clear \\
\hline / Health condition: & $\begin{array}{l}\text { Lain-lain masalah kesih } \\
\text { / Other health problems, }\end{array}$ & $\begin{array}{l}\text { nyatakan jika ada } \\
\text { specify if any: }\end{array}$ \\
\hline
\end{tabular}




\section{BAHAGIAN DUA - Sila tanda $\sqrt{ }$ satu jawapan sahaja}

PART TWO - Please tick $\sqrt{ }$ one answer only

Dari sumber mana anda tahu tentang Program Homestay?

I From what source do you know about the homestay programme?

Agensi Pelancongan / Travel Agency

Media / Media

Laman Sesawang / Internet or Website

Kementerian Pelancongan / Ministry of Tourism

Agensi Kerajaan / Government Agencies

Lain-lain/ Other

Berapakah bayaran yang dikenakan untuk menyertai program homestay?

/ How much is the fees for attending homestay programme?

RM 0-RM 100

RM 101-RM 200

RM 201-RM 300

RM 301-RM 400

RM 401-RM500

Lain-lain. Sila Nyatakan / Others, kindly specify

Mengapa anda menyertai program homestay?

/ Why do you join homestay programme?

Menambahkan pendapatan keluarga / Additional income for family

Isi masa lapang / Fulfill free time

Kesunyian / Loneliness

Menjaring hubungan dengan orang lain / Networking with other people

Lain-lain. Sila Nyatakan / Others, kindly specify

Adakah program homestay ini memenuhi kehendak anda?

I Do you think the homestay programme meet up with your expectation?

\begin{tabular}{l|l}
\hline Ya/ Yes & Kenapa / why \\
\hline Tidak/ No & Kenapa / why \\
\hline
\end{tabular}

Adakah program homestay member manfaat dalam kehidupan anda?

/ Do homestay programme provide you benefits to your life?

\begin{tabular}{l|l}
\hline Ya / Yes & Kenapa / why \\
\hline Tidak / No & Kenapa / why \\
\hline
\end{tabular}

Apakah tahap kepuasan hati anda selepas menyertai program homestay?

/ What is your satisfaction level after attending homestay programme?

Sangat puas hati / Very satisfied

Puas hati / Satisfied

Tidak puas hati / Not satisfied

Apakah masalah atau cabaran yang dihadapi dalam proses pembelajaran program homestay? Sila nyatakan.

I What are the problems or challenges in the process of learning homestay programme? Please specify. 


\section{Interview questions}

Berapa lamakah Kanchong Darat terlibat secara langsung dalam aktiviti homestay?

Since when Kanchong Darat has directly got involved in homestay programme?

Bagaimana penduduk di sini mula terlibat dengan program homestay?

How does villagers started to be involved in the homestay programme?

Bagaimana semuanya bermula dan adakah pihak tuan menerima sebarang bantuan daripada mana-mana pihak sejak memulakan program ini?

How does everything started and do you have any assistance from any parties when you first initiate the programme?

Berapa ramaikah penduduk yang terlibat secara langsung dengan program ini?

How many people are involved directly in the programme?

Bagaimanakah pemilihan dibuat oleh pihak tuan dalam menentukan peserta dalam program ini?

How was the selection process conducted in determining the participant for the programme?

Adakah ianya mendapat sambutan daripada penduduk kampong?

Is it well accepted by the villagers?

Apakah faktor-faktor yang menarik penduduk terlibat dalam program ini?

What are the pulling factors that attract the people to involve in the programme?

Sekiranya kurang penyertaan, apakah faktor-faktor yang menyebabkan program ini kurang disertai?

If there are younger participants, what are the deterrent factors that make them not to join in the programme?

Berapakah majoriti peringkat umur peserta-peserta yang terlibat dalam program ini?

What is the age bracket of the majority of participants involved in the programme?

Berapakah purata pendapatan seorang peserta dalam program ini?

How much the gross income is obtained by a participant in the programme?

Apakah bentuk-bentuk latihan yang diberikan kepada seseorang peserta homestay sebelum mereka layak untuk dipertimbangkan sebagai peserta?

What types of training provided to homestay operators in order for them to qualify as participant under the programme?

Apakah agensi yang terlibat secara langsung dalam pelaksanaan program homestay ini?

Who are the relevant agencies directly involved during the implementation of homestay programme?

Apakah cabaran-cabaran yang dihadapi oleh pihak tuan sebelum dan semasa program ini dijalankan?

What is the challenges face by you before and during the implementation of the programme?

Apakah perancangan pihak tuan pada masa akan datang?

What is your future planning for the programme?

Apakah kebaikan homestay program ini kepada penduduk kampong?

What are the benefits of homestay programme to the villagers? 